\title{
Implementation of Zhu - Takaoka Algorithm on Web-Based Smartphone Price Comparison Applications
}

Guidio Leonarde Ginting*, Barik Alwi

Department of Computer Engineering, STMIK Budi Darma, Medan, Indonesia

\begin{abstract}
This research is motivated by the rise of online buying and selling sites that provide products that are the same as the price differences at each site, from these problems, the authors provide an option by combining several online buying and selling service sites in one website by comparing smartphone prices with the brands provided namely Samsung, Asus, Sony, Lenovo, Nokia, Apple and Xiaomi. Some trusted online buying and selling sites are able to present a variety of information on consumer needs, one of which is its special price competition in the smartphone buying and selling competition which makes the prices in each site online buying and selling services vary even in the same product. Seeing the conditions that occur, where each item displayed in each site has different prices, then consumers are required to be observant in choosing the items sought. Consumers will choose manually by visiting a site that provides goods as a price comparison. Thus consumers will spend a lot of time just looking for price comparisons of one product offered by each site by accessing sites one by one The zhu-takaoka algorithm is one of the string matching algorithms that can do a word search with many shifts with an array of 2 (two) dimensions. The core process of the zhu-takaoka algorithm is to do a word search with the Right-to-left scan rule technique. Each shift in the word search process determines the shift values in the Good Suffix Shift Rule table and Bad-Charcter Shift Rule. With this algorithm, it is expected to facilitate the user in the search process price comparison.
\end{abstract}

Keywords: E-commerce, Zhu - Takaoka

\section{INTRODUCTION}

The development of an Online Shop or online store through internet media has mushroomed in Indonesia, and is even well known to the public. The variety of convenience in shopping and various types of products and services offered, make the Indonesian people make Online Shop as one of the new "shopping places" besides shopping centers.

E-Commerce (Electronic Commerce) or online buying and selling sites is a technology that is growing very rapidly, electronic networks such as the internet. E-Commerce is a way to shop online, both the purchase and sale of goods and services that along with their presence facilitate us in everyday life. Many people benefit from the convenience of doing business through this internet media [1].

The zhu-takaoka algorithm is one of the string matching algorithms that can do a word search with many shifts with an array of 2 (two) dimensions. The core process of the zhu-takaoka algorithm is to do a word search with the Right-to-left scan rule technique. In the previous study, the application of the Zhu-Takaoka algorithm was carried out By implementing it into a dictionary application of music terms so that it can be seen that the Zhu- 
Takaoka algorithm is very efficient for searching multiple patterns because of matching patterns from the end of the pattern [2]. The Zhu-Takaoka algorithm explains that search patterns are carried out starting from each row starting from row to 0 and ending in row to $\mathrm{n} 1-\mathrm{m} 1$. Zhu and Takaoka designed an algorithm that could work using shifts with badcharacters for two successive text characters [3]. By applying the zhu-takaoka algorithm to the application in a very efficient search because the search is done with the Right-to-left scan rule technique, where if there is a discrepancy in the character it is immediately eliminated.

\section{METHODS AND MATERIAL}

\section{A. Applications}

Applications have the meaning of solving problems that use one of the application data processing techniques that usually race on a desired or expected computation and expected data processing. Applications are usually in the form of software in the form of software that contains a unity of orders or programs that are made to carry out a desired job [4]. Application software (software application) is a subclass of computer software that utilizes the ability of a computer directly to perform a task that the user wants [5].

\section{B. Price}

Price is compensation that must be done to obtain a number of goods and services [6] as a medium of exchange to obtain a product or service or it can also be said to determine the value of a product in the minds of consumers. is a visible aspect for buyers, for consumers who do not really understand the technical issues in purchasing services, often prices are the only factor they can understand, not infrequently prices are used as an indicator of service quality.

C. Zhu-Takaoka
The Zhu-Takaoka algorithm is a string matching algorithm published by Zhu Rui Feng and Tadao Takaoka in 1986. In his paper, Zhu and Takaoka refer to the algorithm for matching this string as $\mathrm{BM}$ Algorithm (Boyer-Moore Algorithm). BM Algorithm is a modified algorithm of the Boyer-Moore Algorithm string matching algorithm made by Boyer R.S and Moore J.S. The BM algorithm (Zhu-Takaoka algorithm) which is a modification of the BM Algorithm has the same characteristics in the process of finding a string. These characteristics are the existence of Preprocessing, Right-to-left scan, Badcharacter rule, and Good-suffix rule. The difference between the Boyer-Moore Algorithm and the ZhuTakaoka Algorithm is located at the stage of determining the bad character rule. In Boyer-Moore, bad characters only consist of one-dimensional arrays, while in Zhu-Takaoka they are modified into twodimensional arrays. [10]

\section{RESULTS AND DISCUSSION}

Based on the sample of the smarthpone brand that will be tested, the application of zhu-takaoka algorithm in the search for characters that have Shark text, and the pattern of xioami black shark. Where this process requires the help of the zhutakaoka bad character table and also the good suffixes table, as for the zhu-takaoka bad character table and the boyer-moore table the good suffixes are as follows

\section{A. Table 3.1 Zhu - Takaoka Bad Character}

\begin{tabular}{|c|c|c|c|c|c|c|}
\hline$Z t B c$ & $\mathrm{~A}$ & $\mathrm{H}$ & $\mathrm{K}$ & $\mathrm{R}$ & $\mathrm{S}$ & ${ }^{*}$ \\
\hline $\mathrm{A}$ & $\mathbf{5}$ & 5 & 5 & 1 & 4 & 5 \\
\hline $\mathrm{H}$ & 2 & 5 & 5 & 5 & 4 & 5 \\
\hline $\mathrm{K}$ & 5 & 5 & 5 & 5 & 4 & 5 \\
\hline $\mathrm{R}$ & 5 & 5 & 4 & 5 & 4 & 5 \\
\hline $\mathrm{S}$ & 5 & 3 & 5 & 5 & 4 & 5 \\
\hline$*$ & 5 & 5 & 5 & 5 & 4 & 5 \\
\hline
\end{tabular}

B. Table 3.2 Boyer-Moore Good Suffixes Table

\begin{tabular}{|c|c|c|c|c|c|}
\hline$I$ & 0 & 1 & 2 & 3 & 4 \\
\hline$x[i]$ & $\mathrm{S}$ & $\mathrm{H}$ & $\mathrm{A}$ & $\mathrm{R}$ & $\mathrm{K}$ \\
\hline$b m G s[i]$ & 4 & 4 & 4 & 4 & 1 \\
\hline
\end{tabular}


Step 1

Table 3.3 Table 3.4 Search In Step Text 1

\begin{tabular}{|c|c|c|c|c|c|c|c|c|c|c|c|}
\hline Window & & & & ${ }^{*}$ & ${ }^{*}$ & & & & & & \\
\hline Text & X & I & A & O & M & I & & B & L & A & C \\
\hline Pattern & S & H & A & R & K & & & & & & \\
\hline$I$ & 0 & 1 & 2 & 3 & 4 & & & & & & \\
\hline
\end{tabular}

Unsuitable Character

$Z t B c[*][A]=5$

Step 2 :

Table 3.4 Search In Step Text 2

\begin{tabular}{|c|c|c|c|c|c|c|c|c|c|c|c|}
\hline $\begin{array}{c}\text { Windo } \\
\boldsymbol{W}\end{array}$ & & & & & & & & & & A & \\
\hline Text & X & I & A & O & M & I & & B & L & A & C \\
\hline $\begin{array}{c}\text { Patter } \\
\boldsymbol{n}\end{array}$ & & & & & & S & H & A & R & K & \\
\hline$I$ & & & & & & 0 & 1 & 2 & 3 & 4 & \\
\hline
\end{tabular}

Unsuitable Character

Step 3 :

Table 3.6 Pecarian pada teks langkah 3

\begin{tabular}{|c|r|r|r|r|r|r|r|r|r|r|r|}
\hline $\begin{array}{l}\text { Windo } \\
\boldsymbol{W}\end{array}$ & & & & & & & \multicolumn{1}{|l|}{ S } & H & & & \\
\hline Text & B & L & A & C & K & & S & H & A & R & K \\
\hline $\begin{array}{c}\text { Patter } \\
\boldsymbol{n}\end{array}$ & & & & S & H & A & R & K & & & \\
\hline $\boldsymbol{I}$ & & & & 0 & 1 & 2 & 3 & 4 & & \\
\hline
\end{tabular}

Unsuitable Character

$Z t B c[S][H]=3$

Step 4:

Table 3.7 Table 3.4 Search In Step Text 4

\begin{tabular}{|c|l|l|l|l|l|l|l|l|l|l|l|}
\hline $\begin{array}{c}\text { Windo } \\
\boldsymbol{W}\end{array}$ & & & & & & & & & & & \\
\hline Text & $\mathrm{B}$ & $\mathrm{L}$ & $\mathrm{A}$ & $\mathrm{C}$ & $\mathrm{K}$ & & $\mathrm{S}$ & $\mathrm{H}$ & $\mathrm{A}$ & $\mathrm{R}$ & $\mathrm{K}$ \\
\hline Pattern & & & & & & & $\mathrm{S}$ & $\mathrm{H}$ & $\mathrm{A}$ & $\mathrm{R}$ & $\mathrm{K}$ \\
\hline $\boldsymbol{I}$ & & & & & & & 0 & 1 & 2 & 3 & 4 \\
\hline
\end{tabular}

Match

\section{CONCLUSION}

1. Based on the results of the research conducted, several conclusions were taken, namely: The search process carried out smartphone price comparison application is very helpful because it can do string searches quickly and give the right results.

2. The Zhu-Takaoka algorithm that has been applied to web-based smartphone price comparison applications is very effective in the search process because it generates a lot of information when searching.

3. The design of a smartphone price comparison application produces a simple interface display and an easy display of search output.

\section{REFERENCES}

[1]. S. Ipnuwati, "Perancangan Sistem Informasi Penjualan Pada Toko Minak Singa," Explor. - J. Sist. Inf. dan Telemat., pp. 12-20, 2010.

[2]. Gutman Togatoro, "Implementasi Algoritma zhu-takaoka pada aplikasi kamus berbasis android ", vol. 5, no. 2, pp. 147-153, 2017

[3]. A. K. Kusnadi, Adhi Wicaksono, "Perbandingan Algoritma Horspool dan Algoritma ZhuTakaoka dalam Pencarian String Berbasis Desktop," Ultim. Comput., vol. IX, no. 1, pp. 12-16, 2017.

[4]. R. S. Afandi, "APLIKASI MOBILE INFORMASI KAFE 24 JAM DI YOGYAKARTA BERBASIS ANDROID Pendahuluan Landasan Teori Analisis dan Perancangan Sistem," Dasi, vol. 14, no. 04, pp. 49-53, 2013.

[5]. J. Pseudocode, D. Deslianti, and I. Muttaqin, "Aplikasi kumpulan hadits nabi muhammad saw berbasis," vol. III, pp. 26-34, 2016.

[6]. Riyono and G. E. Budiharja, "Pengaruh Kualitas Produk, Harga, Promosi dan Brand Image terhadapa Keputusan Pembelian Produk Aqua 
di Kota Pati," J. STIE Semarang, , vol. 8, no. 2, pp. 92-121, 2016.

[7]. L. Parmuarip, W. Muslim, and Y. Mulyani, "Alasan Penggunaan Smartphone di Kalangan Mahasiswa Politeknik Negeri Bandung."

[8]. M. Mesran, "Implementasi Algoritma Brute Force Dalam Pencarian Data Katalog Buku Perpustakaan," Maj. Ilm. INTI, vol. 3, no. 1, pp. 100-104, 2014.

[9]. G. G. Maulana, "Pembelajaran Dasar Algoritma Dan Pemrograman Menggunakan El-Goritma Berbasis Web," J. Tek. Mesin, vol. 06, no. 2, pp. 69-73, 2017.

[10]. P. D. Michailidis and K. G. Margaritis, "Experimental Study on Variants of the ZhuTakaoka String Matching Algorithm Experimental Study on Variants of the ZhuTakaoka String Matching Algorithm," no. January 2009, 2014.

[11]. M. F. Maudi, A. L. Nugraha, and B. Sasmito, "Desain Aplikasi Sistem Informasi Pelanggan PDAM WebGIS (Studi Kasus : Kota Demak)," J. Geod. Undip, vol. 3, no. 3, pp. 98-110, 2014.

[12]. R. A. M. Salahuddin, Rekayasa Perangkat Lunak, Modula. 2011.

[13]. A. Nugroho, Rekayasa Perangkat Lunak Berbasis Objek dengan Metode USDP. 2010.

[14]. Bertha Sidik, Framework Codeigniter Menggunakan Framework CI 2.x untuk Memudahkan Pengembangan Pemograman Aplikasi WEB dengan PHP 5

\section{Cite this article as :}

Guidio Leonarde Ginting, Barik Alwin, "Implementation of Zhu - Takaoka Algorithm on Web-Based Smartphone Price Comparison Applications", International Journal of Scientific Research in Science and Technology (IJSRST), Online ISSN : 2395-602X, Print ISSN : 2395-6011, Volume 6 Issue 1, pp. 349-352, January-February 2019. Available at doi : https://doi.org/10.32628/IJSRST196152 Journal URL : http://ijsrst.com/IJSRST196152 